\title{
Leve godt til siste stund...
}

\author{
Lege og medisinhistoriker Ingjald Reichborn-Kjennerud (1865-1949) studerte først filologi. I Tidsskriftet \\ nr. 18/1936 redegjorde han over åtte sider om kilder til vår kunnskap om norsk middelaldermedisin, hvor de \\ er funnet, deres innhold, opprinnelse, pålitelighet osv. (Tidsskr Nor Lægeforen 1936; 56: 1023-30). Nedenfor \\ gjengis et avsnitt av artikkelen med en av hans oversettelser (velegnet til høytlesning).
}

\section{Bruddstykker av latinske lægebøker fra Norges middelalder Av I. Reichborn-Kjennerud, Oslo}

Foruten disse bruddstykker i arkivene som fortjener å bli nærmere undersøkt, dukker det av og til op andre rester av gamle skrifter, også medisinske, innskutt i bøker med annet innhold der de har fått plass på ubrukte steder fordi pergamentet var dyrt og måtte nyttes ut. Da lovbøkene utgjør en stor del av den gamle litteratur som er bevart til vår tid, er det nettop her vi rett som det er, kan støte på slike bruddstykker. Tidligere er det i en avskrift av Frostatingsloven opdaget et stykke med 11 linjer av Salernos helsedikt, skrevet med en hånd fra omkring 1350, men i en annen redaksjon enn den vanlige. ${ }^{5}$ Den latinske tekst har jeg latt trykke før, ${ }^{6}$ og jeg gir nu i fig. 1 en fototypi av originalen og i det følgende en oversettelse:

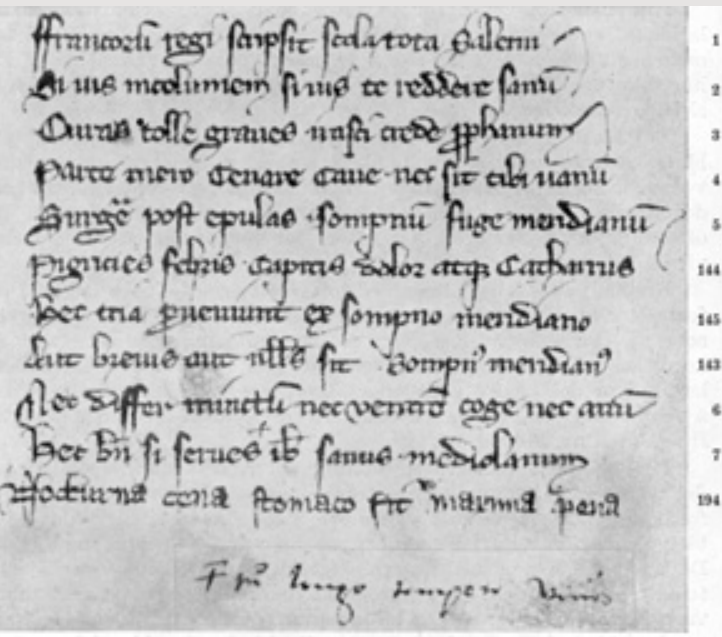

Fig. 1. Fototypi av Ms. Armamag. 309 , fol, 88 i Kjobenhavns univ, bibl.
Salernoskolens læger skrev / til Frankerkongen dette brev:

Vil du ha helsen, frisk og sund / og leve godt til siste stund, bli ikke sint, en simpel skikk / det gjelder være glad og kvikk la sut og sorger fare / på mat og drikke spare.

Stå efter maten hurtig op / til middagssøvn skal du si stopp, for ellers slapp igjen du har / kun feber, hodeverk, katarr. En middagslur skal være kort / men legg den heller ganske bort. Lyd blærens bud og gå på do / trykk ei for hårdt, men sitt i ro, da trenger du ikke å ta no’ / kan frisk dra i vei til Milano. Ved nattmatt har det ofte hendt / at magens lønn var vel fortjent.

\footnotetext{
${ }^{5}$ Norges gamle Love IV, 486 (ms. A. M. nr. fol., bl. 88 recto). Som fototypien av originalen viser (fig. 1) er siste linje skrevet med en annen hånd og varianten nedenunder med en hånd fra 1550-årene. Verslinjenes rekkefølge er en annen enn i den vanlige redaksjon (De Renzi, Collectio Salernitana 1, 445 fg.). Derfor har jeg i margen til høire satt den riktige rekkefølge.

${ }^{6}$ N. Mag. f. Lægev. 1925, 641. Dette norske håndskrift er også til dels utnyttet i min utgave: Lægekunstens blomst, Halden 1933, s. 14, sml. 109.
} 